Social Media, Youths and Political Participation in Malaysia: A Review of Literature

Nor Hafizah Abdullah, Isyaku Hassan, Muhamad Fazil bin Ahmad, Nor Azlili Hassan, Mohd Mahadee Ismail

To Link this Article: http://dx.doi.org/10.6007/IJARBSS/v11-i4/9578

DOI:10.6007/IJARBSS/v11-i4/9578

Received: 14 February 2021, Revised: 10 March 2021, Accepted: 29 March 2021

Published Online: 25 April 2021

In-Text Citation: (Abdullah et al., 2021)

To Cite this Article: Abdullah, N. H., Hassan, I., Ahmad, M. F. bin, Hassan, N. A., \& Ismail, M. M. (2021). Social Media, Youths and Political Participation in Malaysia: A Review of Literature. International Journal of Academic Research in Business and Social Sciences, 11(4), 845-857.

Copyright: () 2021 The Author(s)

Published by Human Resource Management Academic Research Society (www.hrmars.com)

This article is published under the Creative Commons Attribution (CC BY 4.0) license. Anyone may reproduce, distribute, translate and create derivative works of this article (for both commercial and non-commercial purposes), subject to full attribution to the original publication and authors. The full terms of this license may be seen at: http://creativecommons.org/licences/by/4.0/legalcode

Vol. 11, No. 4, 2021, Pg. 845 - 857

Full Terms \& Conditions of access and use can be found at http://hrmars.com/index.php/pages/detail/publication-ethics 


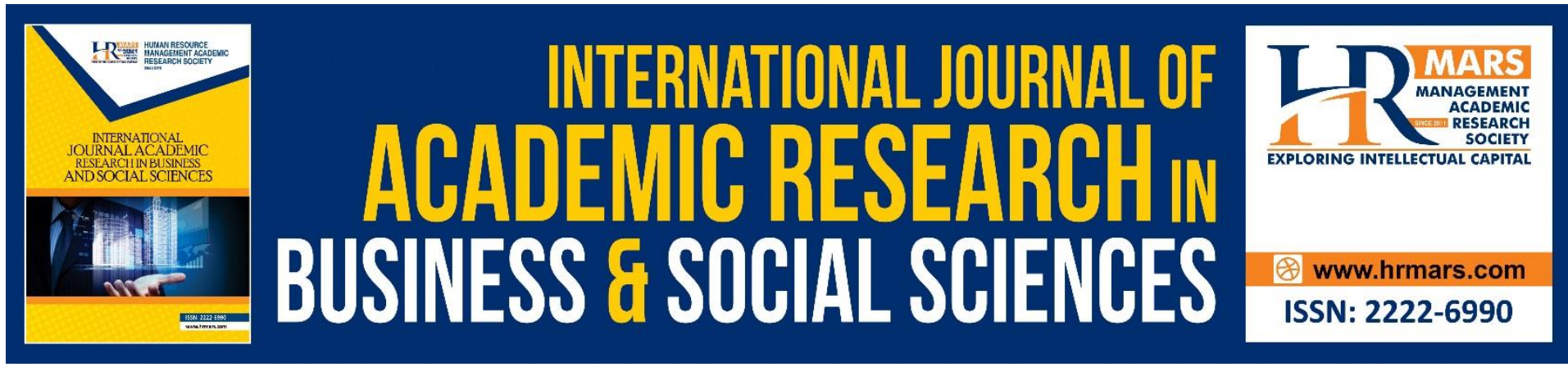

\title{
Social Media, Youths and Political Participation in Malaysia: A Review of Literature
}

\author{
Nor Hafizah Abdullah, Isyaku Hassan \\ Faculty of Languages and Communication, Universiti Sultan Zainal Abidin, Gong Badak \\ Campus, 21300 Kuala Nerus, Terengganu, Malaysia. \\ Muhamad Fazil bin Ahmad \\ Faculty of Applied Social Sciences, Universiti Sultan Zainal Abidin, Gong Badak Campus, \\ 21300 Kuala Nerus, Terengganu, Malaysia.
}

Nor Azlili Hassan

Faculty of Creative Industries, Universiti Tunku Abdul Rahman, 43000 Sg Long Kajang Selangor, Malaysia.

\section{Mohd Mahadee Ismail}

Faculty of Human Ecology, Universiti Putra Malaysia, 43400 Serdang Selangor, Malaysia.

\begin{abstract}
In today's modern world, political knowledge is not only conveyed or sought through traditional methods such as political rallies but also via social media such as Facebook, YouTube and Twitter. The search for political information through social media has now become a global phenomenon. In recent years, the use of social media among youths in Malaysia has increased significantly. It is, thus, prudent to explore the use of social media platforms amongst youths in Malaysian. Therefore, this paper offers a review of studies on youth participation in politics via social media, particularly in the Malaysian context. The paper provides an overview of how Malaysian youths seek political information through social media and reviews recent information related to online resources in the political context. It was envisaged that this paper could advance our understanding of the trend and level of youth participation in politics via social media, particularly in Malaysia. Additionally, this review could provide useful information on the online dissemination and consumption of political information.
\end{abstract}

Keywords: Social Media, Political Information-Seeking Behaviour, Youth, Malaysia

\section{Introduction}

A study conducted by the Malaysian Communications and Multimedia Commission (MCMC) found that Malaysia's internet penetration rate is around 67 percent and active internet users are those aged 20-24 years (24.2 percent) (MCMC, 2016). Besides, it was determined that information-seeking activity is the second most popular online activity, which accounts for 
90.1 percent compared to messaging purposes (92.7 percent) among the community. Furthermore, the broadband penetration rate in Malaysia, which is almost 70 percent and people spend up to 20 hours a week, has placed the internet as a potential source of information (Bunt, 2009) which fosters engagement and political information-seeking behaviour among youth, particularly.

One internet-based communication technology that gains fame around the world is social media. Social media is the most influential communication technology that improves human behaviour in all aspects of life (Lee \& Lim, 2015). Social media is considered the most impactful communication technology that changes human behaviour in all aspects of life (Lee \& Lim, 2015). More than 75 percent of internet users utilise social media as a medium to communicate and share information (Smith, 2011). Hence, it is natural that mobile technology, the internet, and social media have become a social phenomenon among the young generation (Lenhart, Duggan, Perrin, Stepler, Rainie, \& Parker, 2015). There are optimistic views on social media's potential in promoting political engagement among youth (Bennett, 2008; Jenkins, 2006; Levine, 2011; Rheingold, 2008). They can form distinct political groups online, write and publish political issues through blogs and spread political videos on their social networks. The younger generation grew up in an era where social media was part of the culture of learning, games, and communication (Abdullah et al., 2021).

Today's young generation accepts new media such as the internet and other applications for political purposes. For instance, Youtube is taken as a medium of personal video sharing and utilised for downloading and uploading videos of political lectures and other political movements (Bowyer, Kahne, \& Middaugh, 2017). Other social media such as Facebook, Twitter, instant messaging applications such as Whatsapp also play a crucial purpose as a source of information and participation in the political context. This circumstance explains why and how online political information-seeking activities can be seen as an alternative to offline methods that can be used to communicate with friends, converse, ask questions or practices, share beliefs or information with others in matters related to political issues.

An interactive communication technology network empowers the public to obtain a diversity of information sources. The internet also works as a channel of information through multiple social networking platforms that can connect and support social relationships without limited time and space. These qualities challenge conventional media's use as a tool for finding political information. This advanced modish media environment adds value to contemporary society's life and encourages community participation in an essential issue, particularly the political context. Hence, it proves that internet innovation holds many advantages to consumers if utilised for a good purpose.

The search and use of information differ from one individual to another, depending on various circumstances and intentions (Asemi, 2005; Vuylsteke, Wen, Baesens, \& Poelmans, 2010). Searching for an individual's information is influenced by one's aims, tasks, or plans to reduce uncertainty or solve it. These information-seeking activities can also construct the youth generation's social and cognitive capacities in a political context. Therefore, studies on internet-oriented search engine user behaviour have drawn many researchers' recognition in line with its fundamental role as a tool for attaining information (Shen \& Shakir, 2009). In the meantime, an increase in the accessible information on the web also forms informationseeking behaviour (Natarajan, 2012).

\section{Social Media, Youth and Politics}

Several studies focused on youth participation in politics through social media (Hirzalla \& 
Zoonen, 2011; Kim \& Geidner, 2008; Weinstein, 2014). Most of the previous studies indicated that youth participate actively in politics via social media. For example, Weinstein (2014) noted youth widely use social networking sites nowadays. In the context of political participation, the literature demonstrates that the potential for online political participation among youth was low (Kim \& Geidner, 2008). Thus, the researchers argued that, based on the current study, youths' tendency to be active in political activities is different based on the pattern and purpose of why they express themselves and are active in politics online. The same situation applies in a political context where each individual is looking for relevant political information and how it can be used daily. Accordingly, Hassan and Azmi (2018) maintained that people rely on the internet for information and decision-making. Individuals seek information because they attempt to bridge the gap between the situation they are facing and the information needs they require (Westerman et al., 2008). From web 1.0 technology to web 2.0 technology, the internet has altered the way politics acts (Dimitrova \& Bystrom, 2013; Deursen, Dijk \& Helsper, 2014; Iwokwagh \& Okoro, 2012; Westerman et al., 2008). It is a highly democratic 'deliberation space' (Cogburn \& Espinoza-Vasquez, 2011), so much so that it has become a favourite political medium in society (Ternes, Mittelstadt \& Towers, 2014). Thus, it recognises it as a compelling medium for political participation (Campante, Durante \& Sobborio, 2013).

The role performed by the internet in politics has led to the emergence of concepts, such as online participation (Gibson \& Cantijoch, 2013; Gronlund \& Wakabi 2015; Vincente \& Novo 2014); cyber democracy (Chun \& Cho, 2012); digital democracy (Hyun, 2012) and netizens. These concepts lead to situations where the internet serves as a critical participatory tool during political campaigns (Hyun, 2012). Thus, the internet has made the provision of news releases accessible to everyone possible so that politicians can communicate with voters and form online communities. Therefore, the internet facilitates the lives of political candidates through interactivity, which is vital for the functioning of democracy (Zhao, 2014). Moreover, the internet has made social media application in global politics possible (Velenzuela, 2013), such as in education, business and international relations domains (Olabamiji, 2014; Uzochukwu, Patricia \& Ukueze, 2014). In particular, social media for political participation has provided unique online opportunities for communities to connect in democratic processes, permitting them to participate in various forms of political activity that did not exist before (Groshek\& Al-Rawi, 2013; Kauffman, 2009; Mahmood, Bhutta, \& ul Haq, 2018). Consequently, social media plays a vital role in political participation (Hirzalla \& Zoonen, 2011; Ternes et al., 2014).

In the past, only socio-economic, demographic and psychological constituents defined political participation. Nonetheless, in the digital age, evidence implies that Information and Communication Technology (ICT) play an equally vital role (Tolbert \& McNeal, 2003). Therefore, this study covered the interaction of technology, communication and politics. Communication technology impacts behaviours, lifestyles and educates consumers in helping them make decisions appropriate to their lives. One internet-based communication technology that is gaining popularity around the world is social media. Social media is considered the most influential communication technology that transforms human behaviour in all aspects of life (Lim \& Lee-Won, 2017). More than 75 percent of internet users use social media as a medium to express and accord information (Smith, 2011). The effectiveness of social media as a source of political information is increasing and growing in society. In line with the current political culture shift, society is now more content using social media as a current political report source. Furthermore, traditional media's failure in playing its function 
as a communicator of information caused people to start switching to new communication mediums based on the internet and digital media (Salman et al., 2018).

Even though society needs to partake in politics offline, online political participation through social media is just as meaningful (Campante et al., 2018). Moreover, individual participation in national politics is an indispensable ingredient in forming democracy (Varnali \& Gorgulu, 2015). Thus, concerns about declining political participation (Saldana, McGregor \& Gil De Zuniga, 2015) and its implications for well-functioning democracies have motivated scholars to analyse reasons society for participation in politics (Carlisle \& Patton, 2013; Lee, Shah \& McLeod, 2013) among youths. It is because surveys revealed that this group is highly indifferent to politics (Bakker \& De Vreese, 2011; Baumgartner \& Morris, 2010; Mbetera, 2017).

Nevertheless, often, information-seeking and political involvement on social media by youth are very low. Many concerns suggest youth do not have the opportunity to showcase skills in politics. These youths do not comprehend and are uncertain when and how to express their voices and opinions, mainly on social media sites. Usually, some youths' shallow perception of politics also determines their neutrality in their political socialisation. Besides, the youth's engagement with entertainment and pleasure causes them to overlook other more significant elements in their lives, especially in politics. The Malaysian Youth Index (IBM) 2015 attended on 60,000 youths nationwide announced that today's young people are impassive in progressing their political scenario (Nawar Firdaus, 2015). Moreover, the young generation in Malaysia is actively involved in using the internet to find entertainment information, leisure activities and in critical political topics (Amran et al., 2013). They also allocate four hours a day to surf the internet (MCMC, 2016).

Through literature review, some studies considered information-seeking in the context of social media, yet there are still questions and gaps that necessitate answers through additional research. Conclusions from Salman and et al. (2018) pointed that respondents are very concerned about the views shared regarding social media politics. According to Salman et al., respondents also exposed their interest in reading news content or information about political candidates shared on social media. Similarly, a study found that 70 percent of youths obtained from the internet, blogs and Facebook for political preferences (Mat Jali, Besar, Sidek, Ibrahim, Awal, \& Ismail, 2012). Therefore, it confirms that society today is very concerned with what is presented on social media regarding matters involving current politics. Accordingly, future studies must study the credibility of information and news sources on social media so that the information shared does not affect any party's credibility. At the same time, Kushin and Yamamoto (2010) mentioned the need and significance of added research on social media's function in information search and its impact on political decision-making in line with the rapid use of new media in the younger generation. Kaye and Johnson (2004) found that further research on the use of social media in the context of information seeking is imperative to clarify dilemmas such as the issue of what is the motivation behind information seeking on social media, quality information and trust in the information received.

The function operated by social media as an intermediary or medium to motivate youths to seek political information has not been empirically identified. The scenario of seeking political information in new media among youth has yet to be widely explored. Not many studies have been done to examine how social media's role as a medium of the source of political information becomes an impetus or attraction to youth to seek political information. Thus, to fill the gap of scholarly research on political information seeking in Malaysia, the 
researchers were motivated to study the factors contributing to youth's political informationseeking behaviour.

Meanwhile, Ekwenchi and Udenze (2014) claimed that youth indifference towards politics is a global phenomenon that drives an increase in youth demand to participate in politics. This phenomenon is vexatious because an early political partnership among youth is a powerful indicator for future democratic engagement, which could help defend democracy (Bennet, 2008). Social media is a unique platform for providing information and boosting the supply of information as well as facilitating the information-seeking process to gain public attention.

\section{Malaysian Youth Participation in Politics via Social Media}

The purpose of new media such as social media has further increased consumers' dependence to obtain political information in large quantities. In a study conducted by Pepinsky (2013), Malaysia is currently facing political changes due to new media evolution, mainly promoting political liberalisation. This phenomenon will motivate consumers to find and use relevant political information in daily life. The search for political information will reshape an individual's awareness, attitudes and practices. Hence, it will affect political literacy. Political literacy is the skill in finding, understanding, and implementing political information that impacts everyday life's decision-making process, chiefly in politics because community integration's ultimate goal is to have a precise understanding of political knowledge before joining the political domain, such as participation in elections or participation in party activities voluntarily (Shaari, Besar \& Jali, 2017).

Almond (1960) asserted that the description of political patterns includes perception and ensures that observation is also given to the quality and factors of a political institution's integrity or survival or the fall of political power. Political literacy is a major issue leading to problems to date. Following the lack of knowledge and reliance on perceptions and submissive politics, society will experience the country's political process with ambiguity and leads to harmful participation. It worsens as there is a large percentage of not getting involved in politics, including electoral voting.

In general, most individuals are aware that the scenario of society seeking political information has now changed. In the past, society used information without questioning its accuracy, validity and reliability, particularly those involving sources such as magazines and other mass media (Hassan, Azmi, \& Atek, 2015). Now, society is more concerned with the characteristics of information such as accuracy with evidence and reliability, the authenticity of the information, and information that is easy to understand (Hassan et al., 2015; Kim, \& Geidner, 2008). Thus, the publishers or providers of political information should consider the community's sense to understand and translate the information presented in social media for their needs in life. It indicates that the information provided must be able to improve the political literacy of the community continuously. In addition to seeking information, society can also assess the quality of political information provided, seek information in-depth, assess the reliability of political information sources and understand the pros and cons of information obtained through social media (Hassan, Azmi, \& Abdullahi, 2020).

In the Malaysian setting, research shows that social media users spend a lot of their time on social media platforms. For example, Mustafa and Hamzah (2011), who surveyed local social media networks, found that in Malaysia,s social media users spend quite many hours online. According to Syahrir (2009), the use of social networking applications in Malaysia has recorded 66\% in December 2008, ranked third in Asia after Singapore. The most popular social network is the Facebook page with 6.2 million visitors, followed by Friendster with 4.2 million 
people, MySpace with 2.1 million people and Twitter with about 750,000 visitors (Jafarkarimi et al., 2016). According to Jafarkarimi et al., this phenomenon has a reflective impression on Malaysian youths' lives. Some youths make social media an initial routine before doing other daily activities, and youths are among the majority users of social networks.

The expansion of communication technology increasingly gains researchers' attention, especially social media, a phenomenon worldwide (Schlagwein \& Prasarnphanich, 2014). According to Prybutok and Ryan (2015), youths are an active group that uses social media for various purposes such as communicating, entertainment, information-seeking, information dissemination, and information exchange, finding new contacts, building virtual groups and running a business. Youths are active users of social media in Malaysia (MCMC, 2016). Social media adoption among Malaysian youth shows a similar pattern globally (Schlagwein, \& Prasarnphanich, 2014). Apart from entertaining themselves with game applications, Malaysian youths also use social media to learn (Isaias et al., 2014). They use Facebook, YouTube, and Dropbox to learn in class, communicate, and connect with lecturers during learning activities outside of lecture time. Hence, it proposes that Malaysian youths are active in social media in entertainment and use it as a medium to obtain valuable knowledge in their daily lives.

According to Ahmad, Ismail, and Nasir (2015), social media in Malaysia has excellent potential in information sharing for educational purposes, especially in the context of learning. The research observed that Malaysian youths use more than one social media type for information sharing and information seeking. It proves that the use of social media will continue to increase over time. This phenomenon will be even more enjoyable with various social media types and its ability to adapt to smartphones' sophistication, the principal communication tools among the youth.

Youth are the group that dominates the use of social media for various purposes (MCMC, 2016). As a highly dependent group on social media use for various purposes, it is detrimental if the youth do not utilise this technology for their benefit. Youth handle social media for various purposes, such as getting various news and information of new friends, obtaining religious information, entertainment, and seeking political information. Social media is a multi-functional resource with capacities in terms of social bonding, emotional sharing, and openness, but it also serves to educate users with information with various themes. Social media provides a unique platform for sharing information and knowledge in individual and group contexts.

Past studies have also shown a lack of research focus on the types of political information sought by consumers. It implies that the research scope involving social media is constantly evolving and is of concern to researchers. Furthermore, social media is also considered a medium that serves as a bank of information to the public. The abundance of political information available on social sites or social media is a usable source by individuals in obtaining information. This abundance of information will challenge them to obtain reliable and fitting information for their individual needs. Thus, consumers need to be skilled and own political literacy in reading political information. In the success of the information search process in the context of social media, the need for the ability to interpret and understand the information to be sought is an essential indicator. The relevance of literacy and political information-seeking remains unexplored in Malaysia, especially in youth.

Recent studies on social media use and the search for political information among youth globally show diversity in the study's focus, the study's subjects, and the methods used. Studies on the search for political information involving youth have not been widely explored 
in the local context. Previous studies on youth-related social media use in Malaysia have primarily focused on the motives and frequency of social media users, preferences, and internet dependence and online activities that are more focused on virtual social interactions with selected social media (Ahmad et al., 2015; Isaias et al., 2014; Jafarkarimi et al., 2016; Yusop, \& Sumari, 2013).

Nevertheless, reading the political information search scenario has become an urgent topic and increasingly gained researchers' attention. Through a review of the literature, several studies explore information-seeking in the context of social media, yet there are still questions and gaps that need answers through further research. The findings of Salman et al. (2018) recorded that respondents are very concerned about the views shared regarding social media politics. Besides, respondents expressed their interest in reading news content or information about political candidates shared on social media. These findings are in line with a study conducted by Mat Jali et al. (2012) in which 70 percent of the respondents agreed that all the information obtained from the internet, blogs and even Facebook had influenced political tendencies among Indian youth in public universities. This, to some extent, reveals that society today is very concerned with what is displayed on social media regarding matters involving current politics. Therefore, future studies must examine the credibility of information and news sources on social media so that the information shared does not affect any party's credibility. At the same time, Kushin and Yamamoto (2010) highlighted the need and interest of further research on social media's function in information search and its impact on political decision-making in line with the rapid use of new media for the younger generation.

Systematic analysis of work reviews by Kaye and Johnson (2004) discovered that further research on the use of social media in the context of information seeking is imminent to elucidate problems such as the issue of the motivation behind information seeking on social media, quality information, and trust in the information received. Nonetheless, these studies do not discuss the factors that contribute to the search for political information explicitly. The question of why social media is an option for obtaining political information and how sociodemographic profiles assist in media selection is also not addressed in detail. According to Lambert and Loiselle (2007), elements of an individual's sociodemographic characteristics and personal background will determine the extent to which information retrieval will occur.

The role performed by social media as an intermediary or medium to motivate youths to seek political information has not been empirically identified. The scenario of seeking political information in the context of new media among Malaysian youth has not been widely explored. Not many studies have been done to examine the extent to which the role of social media as a medium of political information source becomes an impetus or attraction to youth for the search for political information. Consequently, to fill the gaps in scientific research on political information seeking in Malaysia, researchers were motivated to study the factors contributing to youth's political information-seeking behaviour.

\section{Conclusion}

This paper focused on a review of studies that focused on youth participation in politics via social media, particularly in the Malaysian context. The paper provided an overview of how Malaysian youths seek political information through social media and reviewed recent information related to online resources in the political context. It was found that most social media users in Malaysia are youths who use various social media platforms, such as Facebook and YouTube, as primary sources of political information. Social media platforms help 
Malaysian youths to search for political information and assess its quality and reliability as well as pros and cons. They have provided Malaysian youths with the opportunity to question the accuracy, validity and reliability of political information. Generally, social media platforms have increased youth political participation in Malaysia due to their interactivity and attractiveness.

It was envisaged that this paper could be useful to the government and politicians in planning the online distribution of political information. Political information should be pertinent and relevant to the needs, wants, goals and situation of youths. This, in turn, could lead to effective and credible political information that can be used to enhance political hygiene. Additionally, the paper could advance our understanding of the trend and level of youth participation in politics via social media, particularly in Malaysia. Nevertheless, previous research has primarily focused on the youth motives, attitudes, and levels of social media usage for political information. Therefore, further research may focus on the types and credibility of political information sought by youths.

\section{References}

Abdul Razak, N., Saeed, M., \& Ahmad, Z. (2013). Adopting Social Networking Sites (SNSs) as interactive communities among English Foreign Language (EFL) learners in writing: Opportunities and challenges. English Language Teaching. 6(11), 187-198. doi: 10.5539/elt.v6n11p187

Abdullah, N. H., Hassan, I., Ahmad, M. F., Omar, F. I., \& Azmi, M. N. L. (2021). YouTube usage and youth netizens' behaviors: A correlational study. Quantum Journal of Social Sciences and Humanities, 2(2), 56-64.

Ahmad, J. H., Ismail, N., \& Nasir, N. N. A. (2015). Investigating Malaysian Youth's Social Media Usage, Competencies and Practice with regard to Crime Prevention: An Application of the Social Media Literacy Model. Retrieved from: http://eprints.usm.my/32058/1/Nurzali,_Jamilah,_Nur.pdf

Amran, N., Saiful Bahry, F. D., Anwar, N., \& Abu Bakar, R. (2013). Internet usage behaviors among young teenagers. Journal of Information and Knowledge Management (JIKM), 3(1), 51-62.

Asemi, A. (2005). Information searching habits of Internet users: A case study on the Medical Sciences University of Isfahan, Iran. Webology, 2(1), 1-11.

Bakker, T. P., \& De Vreese, C. H. (2011). Good news for the future? Young people, Internet use, and political participation. Communication research, 38(4), 451-470.doi: $10.1177 / 0093650210381738$

Baumgartner, J. C., \& Morris, J. S. (2010). MyFaceTube politics: Social networking web sites and political engagement of young adults. Social Science Computer Review, 28(1), 2444.doi: 10.1177/0894439309334325

Bennett, W. L. (2008). Civic life online: Learning how digital media can engage youth. Cambridge: The MIT Press.

Bowyer, B. T., Kahne, J. E., \& Middaugh, E. (2017). Youth comprehension of political messages in YouTube videos. new media \& society, 19(4), 522-541.

doi: $10.1177 / 1461444815611593$

Campante, F., Durante, R., \& Sobbrio, F. (2018). Politics 2.0: The multifaceted effect of broadband internet on political participation. Journal of the European Economic Association, 16(4), 1094-1136.doi: 10.1093/jeea/jvx044 
Carlisle, J. E., \& Patton, R. C. (2013). Is social media changing how we understand political engagement? An analysis of Facebook and the 2008 presidential election. Political research quarterly, 66(4), 883-895.doi: 10.1177/1065912913482758

Chun, S., \& Cho, J. S. (2012). E-participation and transparent policy decision making. Information Polity, 17(2), 129-145.

Cogburn, D. L., \& Espinoza-Vasquez, F. K. (2011). From networked nominee to networked nation: Examining the impact of Web 2.0 and social media on political participation and civic engagement in the 2008 Obama campaign. Journal of political marketing, 10(1-2), 189-213.

Dimitrova, D. V., \& Bystrom, D. (2013). The effects of social media on political participation and candidate image evaluations in the 2012 lowa caucuses. American Behavioral Scientist, 57(11), 1568-1583.

Ekwenchi, O. C., \& Udenze, S. (2014). Youth and political apathy: Lessons from a social media platform. International Journal of Social Sciences and Humanities Review, 4(4), 1-8.

Gibson, R., \& Cantijoch, M. (2013). Conceptualizing and measuring participation in the age of the internet: Is online political engagement really different to offline?. The Journal of Politics, 75(3), 701-716.doi: 10.1017/s0022381613000431

Grönlund, Å., \& Wakabi, W. (2015). Citizens' use of new media in authoritarian regimes: a case study of Uganda. The Electronic Journal of Information Systems in Developing Countries, 67(1), 1-23.doi: 10.1002/j.1681-4835.2015.tb00479.x

Groshek, J., \& Al-Rawi, A. (2013). Public sentiment and critical framing in social media content during the 2012 US presidential campaign. Social Science Computer Review, 31(5), 563576.doi: 10.1177/0894439313490401

Hassan, I., \& Azmi, M. N. L. (2018). Readers' preferences for print and online newspapers in Northwestern Nigeria. International Journal of Academic Research in Business and Social Sciences, 9 (6), 965-974. doi:10.6007/IJARBSS/v8-i6/4294

Hassan, I., Azmi, M. N. L., \& Abdullahi, A. M. (2020). Evaluating the spread of fake news and its detection techniques on Social Networking Sites. Romanian Journal of Communication and Public Relations, 22(1), 111-125.

Hassan, I., Azmi, M. N. L., \& Atek, E. S. (2015). Measuring readers' satisfaction with online newspaper contents: A study of Daily Trust, American Journal of Innovative Research and Applied Sciences, 1 (8), 304-311.

Hirzalla, F., \& Zoonen, L. V. (2011). Beyond the online/offline divide: How youth's online and offline civic activities converge. Social Science Computer Review, 29(4), 481-498.doi: $10.1177 / 0894439310385538$

Hyun, K. D. (2012). Americanization of web-based political communication? A comparative analysis of political blogospheres in the United States, the United Kingdom, and Germany. Journalism \& Mass Communication Quarterly, 89(3), 397-413.doi: $10.1177 / 1077699012447919$

Isaias, P., Kommers, P., Issa, T., Lim, J. S. Y., Agostinho, S., Harper, B., \& Chicharo, J. (2014). The engagement of social media technologies by undergraduate informatics students for academic purpose in Malaysia. Journal of Information, Communication and Ethics in Society, 12(3), 177-194. doi: 10.1108/JICES-03-2014-0016/full/html

Iwogwagh, N. S., \& Okoro, G. S. (2012). Social Media and Citizen Engagement in the 2011 Presidential Election in Nigeria. Paper presented at the International Conference on Communication, Media and Technology Design, Istanbul, Turkey. 
Jafarkarimi, H., Sim, A. T. H., Saadatdoost, R., \& Hee, J. M. (2016). Facebook addiction among Malaysian students. International Journal of Information and Education Technology, 6(6), 465-469. doi: 10.7763/IJIET.2016.V6.733

Kauffman, H. J. (2009). Political discourse and participation utilizing Web 2.0 technologies. Washington: Gonzaga University Press.

Kaye, B. K., \& Johnson, T. J. (2004). A Web for all reasons: uses and gratifications of Internet components for political information. Telematics and informatics, 21(3), 197-223.doi: 10.1016/S0736-5853(03)00037-6

Kim, Y., \& Geidner, N. (2008). Politics as friendship: The impact of online social networks on young voters' political behavior. Paper presented at the annual convention of the International Communication Association, Montreal, Canada.

Kushin, M. J., \& Yamamoto, M. (2010). Did social media really matter? College students' use of online media and political decision making in the 2008 election. Mass Communication and Society, 13(5), 608-630.doi: 10.1080/15205436.2010.516863

Lambert, S. D., \& Loiselle, C. G. (2007). Health information-seeking behavior. Qualitative health research, 17(8), 1006-1019.doi: 10.1177/1049732307305199

Lee, N. J., Shah, D. V., \& McLeod, J. M. (2013). Processes of political socialization: A communication mediation approach to youth civic engagement. Communication Research, 40(5), 669-697.doi: 10.1177/0093650212436712

Lee, Y., \& Lim, Y. K. (2015). Understanding the Roles and Influences of Mediators from Multiple Social Channels for Health Behavior Change. Paper presented at the 18th Conference on Computer Supported Cooperative Work \& Social Computing, Vancouver BC, Canada.

Lenhart, A., Duggan, M., Perrin, A., Stepler, R., Rainie, H. \& Parker, K. (2015). Teens, Social Media \& Technology Overview 2015. Retrieved from:

http://www.pewinternet.org/2015/04/09/teens-social-media-technology-2015.

Lim, Y. S., \& Lee-Won, R. J. (2017). When retweets persuade: The persuasive effects of dialogic retweeting and the role of social presence in organizations' Twitter-based communication. Telematics and informatics, 34(5), 422-433.doi: 10.1016/j.tele.2016.09.003

Mahmood, Q. K., Bhutta, M. H., \& ul Haq, M. A. (2018). Effects of sociodemographic variables and Facebook group membership on students political participation. Education and Information Technologies, 23(5), 2235-2247.doi: 10.1007/s10639-018-9715-5

Malaysian Communications and Multimedia Comission. (2016). Communications and multimedia pocket book of statistics 2016. Cyberjaya. https://www.mcmc.gov.my/skmmgovmy/media/General/pdf/1H-2016-CM-PocketBook_revised.pdf

Jali, M. F., Besar, A. J., Sidek, A. H., Ibrahim, Y., Awal, M. N. A., \& Ismail, K. (2012). Politik pembangunan dalam pilihan raya kecial Dewan Undangan Negeri (DUN) Batang Air, Sarawak. Jurnal E-Geografia, 8(2), 88-97.

Mbetera, F. M. (2017). Social Media Use and Participatory Politics among Students in Universities in Nairobi, A critical examination of political use of social media by university students in Nairobi (Doctoral dissertation). University of Nairobi, Kenya.

Mustafa, S. E., \& Hamzah, A. (2011). Online social networking: A new form of social interaction. International Journal of Social Science and Humanity, 1(2), 96-104.

Natarajan, M. (2012). Information-seeking behavior of students of Management Institutions in NCR of Delhi. Trends in Information Management, 8(2), 100-110. 
Olabamiji, O. M. (2014). Use and misuse of the new media for political communication in Nigeria's Fourth Republic. Developing Country Studies, 4(4), 92-102.

Pepinsky, T. B. (2013). The new media and Malaysian politics in historical perspective. Contemporary Southeast Asia, 35(1), 83-103.

Prybutok, G., \& Ryan, S. (2015). Social media: the key to health information access for 18-to 30-year-old college students. CIN: computers, informatics, nursing, 33(4), 132-141. doi: $10.1097 / \mathrm{CIN} .0000000000000147$

Saldaña, M., McGregor, S. C., \& Gil de Zúñiga, H. (2015). Social media as a public space for politics: Cross-national comparison of news consumption and participatory behaviors in the United States and the United Kingdom. International Journal of Communication, 9(1), 3304-3326.

Salman, A., Yusoff, M. A., Salleh, M. A., \& Abdullah, M. Y. (2018). Penggunaan media sosial untuk sokongan politik di Malaysia. Journal of Nusantara Studies 3 (1), 51-63. doi:10.24200/jonus.vol3iss1 pp51-63

Schlagwein, D., \& Prasarnphanich, P. (2014). Social media around the GLOBE. Journal of Organizational Computing and Electronic Commerce,24(2-3), 122-137.doi: 10.1080/10919392.2014.896713

Shaari, S. S., Besar, J. A., \& Jali, M. F. M. (2017). Analysis of the Effectiveness of Ethnic Relations Subject as Political Literacy Trigger: A Study of UNIKL MIIT Students). e-Bangi, 14(6), 18.

Shen, K., \& Shakir, M. (2009). Internet usage among young Arab students: Preliminary findings. Paper presented at the European, Mediterranean and Middle Eastern Conference on Information Systems, Abu Dhabi, United Arab Emirates.

Smith, A. (2011). Why Americans use social media. Retrieved from https://www.pewresearch.org/internet/2011/11/15/why-americans-use-socialmedia/.

Ternes, A., Mittelstadt, A., \& Towers, I. (2014). Using Facebook for Political Action. Social Networking Sites and Political Participation of Young Adults. Arabian Journal of Business and Management Review, 5(1). 1-16. doi:10.4172/2223-5833.1000106

Tolbert, C. J., \& McNeal, R. S. (2003). Unraveling the effects of the Internet on political participation?. Political research quarterly, 56(2), 175-185.doi: 10.1177/106591290305600206

Uzochukwu, C. E., Patricia, U. E., \& Ukueze, C. A. (2014). Harnessing social media tools in the fight against corruption in Nigeria: Challenges and prospects. International Journal of Social Relevance Communication, 2(11), 5-14.

Valenzuela, S. (2013). Unpacking the use of social media for protest behavior: The roles of information, opinion expression, and activism. American behavioral scientist, 57(7), 920-942.doi: 10.1177/0002764213479375

Van Deursen, A., van Dijk, J., \& Helsper, E. (2014). Investigating outcomes of online engagement. Retrieved from: http://eprints.Ise.ac.uk/59994/

Varnali, K., \& Gorgulu, V. (2015). A social influence perspective on expressive political participation in Twitter: the case of\# OccupyGezi. Information, Communication \& Society, 18(1), 1-16.doi: 10.1080/1369118X.2014.923480

Vicente, M. R., \& Novo, A. (2014). An empirical analysis of e-participation. The role of social networks and e-government over citizens' online engagement. Government Information Quarterly, 31(3), 379-387.doi: 10.1016/j.giq.2013.12.006 
Vuylsteke, A., Wen, Z., Baesens, B., \& Poelmans, J. (2010). Consumers' search for information on the internet: how and why China differs from Western Europe. Journal of Interactive Marketing, 24(4), 309-331.doi: 10.1016/j.intmar.2010.02.010

Weinstein, E. C. (2014). The personal is political on social media: Online civic expression patterns and pathways among civically engaged youth. International Journal of Communication, 8(1), 210-233.

Westerman, D., Van Der Heide, B., Klein, K. A., \& Walther, J. B. (2008). How do people really seek information about others?: Information seeking across Internet and traditional communication channels. Journal of Computer-Mediated Communication, 13(3), 751767.doi: 10.1111/j.1083-6101.2008.00418.x

Yusop, F. D., \& Sumari, M. (2013). The use of social media technologies among Malaysian youth. Procedia - Social and Behavioral Sciences 103(1), 1204-1209. doi: 10.1016/j.sbspro.2013.10.448

Zhao, Y. (2014). New Media and Democracy: 3 Competing Visions from Cyber-Optimism and Cyber Pessimism. Journal of Political Sciences \& Public Affairs, 2(1), 114-118. doi: 10.4172/2332-0761.1000114 